\title{
Review on Utilization of Plants for the Phytoremidiation Purpose on Heavy Metal Contaminated Soil
}

\author{
Ewnetu Teshale \\ Jimma Agricultural Research Center, P. O. Box 192, Jimma, Ethiopia
}

\begin{abstract}
Heavy metal pollution in the soil has been the main environmental problems in recent years all over the world. Heavy metals that are commonly contaminating soil include lead, chromium, arsenic, zinc, cadmium, copper, mercury and nickel. The main sources of these metals are dust produced by energy, transport, metallurgy, production of construction materials; sanitary sewage, chemical wastewater, industrial mining wastewater and urban mining mixed sewage; mining and industrial solid waste contamination, Fertilizers and pesticides are important agricultural inputs for agricultural production and there is a growing public concern over the potential accumulation of heavy metals in soil owing to rapid industrial development and also the heavy metals pollution is one of the problems that arise due to the increased uses of fertilizers and other chemicals to meet the higher demands of food production for human consumption. Heavy metals exhibit toxic effects towards soil biota by affecting key microbial processes and decrease the number and activity of soil microorganisms. Even low concentration of heavy metals may inhibit the physiological metabolism of plant. Plants growing on these soils show a reduction in growth, performance, and yield. Uptake of heavy metals by plants and subsequent accumulation along the food chain is a potential threat to animal and poses serious health risks to humans. To overcome the problem phytoremediation using of plants to reduce the concentrations or toxic effects of heavy metal contaminants in the environments and relatively recent technology which perceived as cost-effective, efficient remedy of soils by improving phisico-chemical of the soil with cheap and practically acceptable techniques.
\end{abstract}

Keywords: Contaminants, Heavy metal, Phytoremediation, Soil, Toxic

DOI: $10.7176 / \mathrm{JNSR} / 9-6-03$

Publication date:March $31^{\text {st }} 2019$

\section{Introduction}

Soil pollution by heavy metals is a significant environmental problem worldwide In particular; heavy metal pollution of surface soils due to intense industrialization and urbanization has become a serious concern in many developing countries (Mireles et al., 2012). The accumulation of heavy metals in surface soils is affected by many environmental variables, including parent material and soil properties, as well as by human activities, such as industrial production, traffic, farming, and irrigation. Large areas of land can be contaminated by heavy metals released from smelters, waste incinerators, industrial wastewater, and from the application of sludge or municipal compost, pesticides, and fertilizers. Irrespective of their sources in the soil, accumulation of heavy metals can degrade soil quality, reduce crop yield and the quality of agricultural products, and thus negatively impact the health of human, animals, and the ecosystem (Nagajyoti et al., 2010).

Soil is a long-term sink for the group of potentially toxic elements often referred to as heavy metals, including zinc $(\mathrm{Zn})$, copper $(\mathrm{Cu})$, nickel $(\mathrm{Ni})$, lead $(\mathrm{Pb})$, chromium $(\mathrm{Cr})$ and cadmium $(\mathrm{Cd})$. Whilst these elements display a range of properties in soils, including differences in mobility and bioavailability, leaching losses and plant uptake are usually relatively small compared to the total quantities entering the soil from different agricultural sources. As a consequence, these potentially toxic elements slowly accumulate in the soil profile over long periods of time. This could have long term implications for the quality of agricultural soils, including phytotoxicity at high concentrations, the maintenance of soil microbial processes, and the transfer of zootoxic elements to the human diet from increased crop uptake or soil ingestion by grazing livestock (Nicholson et al., 2003).

Phytoremediation is an ecofriendly approach for remediation of contaminated soil and water using plants and comprised of two components, one by the root colonizing microbes and the other by plants themselves, which degrade the toxic compounds to further non-toxic metabolites (Ali et al., 2013). Various compounds such as organic compounds, xenobiotics, pesticides and heavy metals, are among the contaminants that can be effectively remediated by plants. Phytoremediation is the one captivating solution for this problem is to use green plants for Heavy Metal removal from soil and render it harmless and reusable(Van Aken, 2009). Although this green technology has many advantages over conventional methods of Heavy metal removal from soils, the objectives of this paper was to review source heavy metal effects on soil, plant growth, soil microorganisms and human health and also its remediation approach through phytoremediation. 
Table 1: Sources of heavy metals in soils Source

\begin{tabular}{|l|l|}
\hline $\begin{array}{l}\text { Name of the } \\
\text { contaminant }\end{array}$ & \multicolumn{1}{|c|}{ Source } \\
\hline Arsenic (As) & $\begin{array}{l}\text { Timber treatment, paints, pesticides, geothermal, geogenic/natural processes, } \\
\text { smelting operations, thermal power plants, fuel burning }\end{array}$ \\
\hline Cadmium (Cd) & $\begin{array}{l}\text { Electroplating, batteries, fertilizers, Zinc smelting, waste batteries, e-waste, paint } \\
\text { sludge, incinerations\& fuel combustion }\end{array}$ \\
\hline Chromium (Cr) & $\begin{array}{l}\text { Timber treatment, leather tanning, pesticides, dyes, Mining, industrial coolants, } \\
\text { chromium salts manufacturing }\end{array}$ \\
\hline Copper (Cu) & $\begin{array}{l}\text { Fungicides, electrical, paints, pigments, timber treatment, fertilizers, mine tailings, } \\
\text { electroplating, smelting operations }\end{array}$ \\
\hline Lead (Pb) & $\begin{array}{l}\text { Batteries, metal products, preservatives, petrol additives, paints, e-waste, Smelting } \\
\text { operations, coal based thermal power plants, ceramics, bangle industry }\end{array}$ \\
\hline Manganese (Mn) & Fertilizer \\
\hline Mercury (Hg) & $\begin{array}{l}\text { Instruments, fumigants, geothermal, chlor-alkali plants, thermal power plants, } \\
\text { fluorescent lamps, hospital waste (damaged thermometers, barometers, } \\
\text { sphygmomanometers), electrical appliances etc. }\end{array}$ \\
\hline Molybdenum (Mo) & Fertilizer, spent catalyst \\
\hline Nickel (Ni) & Alloys, battery industry, mine tailings, smelting operations, thermal power plants, \\
\hline Zinc (Zn) & $\begin{array}{l}\text { Galvanization, dyes, paints, timber treatment, fertilizers, mine tailings, smelting, } \\
\text { electroplating }\end{array}$ \\
\hline
\end{tabular}

Source: Lone et al. (2008)

\subsection{Effects of Heavy Metal Contamination on Agriculture}

The heavy metals are being introduced into soils from various sources, including atmospheric pollution by metalbearing particles, application of sewage sludge, waste water irrigation, phosphate fertilizer, pesticides and pig slurry, where they exist in several chemical forms. As consequence of the heavy metal contamination of agricultural soils has become one of the most significant environmental problems. Excessive amount of heavy metal accumulation in agricultural soils through wastewater irrigation, may not only cause soil contamination, but also leads to elevated heavy metal uptake by crops, and thus affect food quality and safety (Chabukdhara et al., 2016). Heavy metal accumulation in soils and plants is of increasing concern because of the potential human health risks associated with soil-crop-food chain transfer. Accumulation of toxic metals in edible parts of crops grown in contaminated soils has been reported from number of crops including rice, soybean, wheat, maize, and vegetables. In fact plants may have their growth sharply reduced can result in decreased crop yield too due to the inhibition of plant metabolic processes (Singh and Aggarwal, 2006). The accumulation of metals in agricultural crops and thresholds of dietary toxicity in soil-crop system may vary with several factors like crop management practices and soil properties (Cooper et al., 2011).

\subsection{Impacts of Heavy Metal Polluted Soil on Plant Growth}

The heavy metals that are available for plant uptake are those that are present as soluble components in the soil solution or those that are easily solubilized by root exudates (Blaylock and Huang, 2000). Although plants require certain heavy metals for their growth and upkeep, excessive amounts of these metals can become toxic to plants. The ability of plants to accumulate essential metals equally enables them to acquire other nonessential metals (Chibuike and Obiora, 2014) As metals cannot be broken down, when concentrations within the plant exceed optimal levels, they adversely affect the plant both directly and indirectly. Some of the direct toxic effects caused by high metal concentration include inhibition of cytoplasmic enzymes and damage to cell structures due to oxidative stress (Bhagure and Mirgane, 2011). An example of indirect toxic effect is the replacement of essential nutrients at cation exchange sites of plants (Taiz and Zeiger, 2002) further, the negative influence heavy metals have on the growth and activities of soil microorganisms may also indirectly affect the growth of plants. For instance, a reduction in the number of beneficial soil microorganisms due to high metal concentration may lead to decrease in organic matter decomposition leading to a decline in soil nutrients. Enzyme activities useful for plant metabolism may also be hampered due to heavy metal interference with activities of soil microorganisms. These toxic effects (both direct and indirect) lead to a decline in plant growth which sometimes results in the death of plant (Sheldon and Menzies, 2005).

\subsection{Effects on soil microorganisms}

Microbial activity and enzymatic activity of the soil can sensitively reflect the quality of the soil held that microbial 
biomass of the soil was an important indicator of determining the extent of soil contamination. Microbial activity is inhibited significantly in the heavy metal contaminated soil. Sobolev et al. (2008) indicated that the microbial biomass in the soil contaminated by $\mathrm{Cu}, \mathrm{Zn}, \mathrm{Pb}$ and other heavy metals were inhibited severely. The soil's microbial biomass near the mine was significantly lower than that far away from the mine. The effects of different concentrations of heavy metals and different heavy metals on soil microbial biomass were different. Liu et al. (2017) studied the effect of different concentrations of heavy metals on soil microbial biomass, and found that only if the concentration of heavy metals in the soil was three times above the environmental standard, established by the European Union, it could inhibit microbial biomass. Bruins et al. (2000) found that low concentrations of heavy metals could stimulate microbial growth and increase microbial biomass while high concentrations could decrease soil microbial biomass significantly. In addition, the enzymes in the soil play an important role in the process of organic matter decomposition and nutrient cycling. Studies have showed that the activities of enzymes in the soil are related to the heavy metal contamination. Bong et al. (2010) found that the activities of almost all enzymes in the soil were significantly reduced by 10 to 50 times with the increase of the concentration of heavy metals. However, it is one of the richest reservoirs of microorganisms, i.e. 1 gram of agricultural soil may contain even several billion colony forming units (CFUs) of microorganisms belonging to thousands of different species (Roselló and Amann, 2001).Destruction of the soil microbiota through mismanagement or environmental pollution such as heavy metal causes decline or even death of the aboveground plant and animal populations (Kinney, 2004).

\subsection{Heavy Metals Problems on Human Health}

In recent years several study have shown that heavy metal in agricultural soil are absorbed and accumulated by crops ingesting heavy metals through the soil crop system is a major way of damaging human health (Aeliona $e t$ al., 2008) The increasing demand of food safety has accelerated research regarding the risk associated with food consumption contaminated by heavy metals (Mansour et al., 2009). The rate at which heavy metals are accumulated in the soil depends on the physiochemical properties of the soil and the relative efficiency of crops to remove the metals from the soil. Heavy metals accumulated in cultivated soils can be transferred to humans through various exposure pathways causing adverse effects on human health (Qishlaqi et al., 2008 The excessive amount of these metals in food is associated with etiology of a number of diseases, especially with cardiovascular, kidney, nervous as well as bone diseases (Steenland and Boffetta, 2000). Heavy metal-contaminated food can seriously deplete some essential nutrients in the body that are further responsible for decreasing immunological defenses, intrauterine growth retardation, impaired psychosocial faculties, disabilities associated with malnutrition and high prevalence of upper gastrointestinal cancer rates (Arora et al., 2008). Serious systemic health hazards can develop as a result of extreme dietary accumulation of heavy metals such as $\mathrm{Cr}, \mathrm{Cd}, \mathrm{Ni}$ and $\mathrm{Pb}$ (Bhagure and Mirgane, 2011).

\subsection{Plants that are used for phytoremediation of Heavy metals}

Plants act as solar-driven pumping and filtering systems as they take up contaminants (mainly water soluble) through their roots and transport/translocate them through various plant tissues where they can be metabolized, sequestered, or volatilized (Olguín and Galván, G., 2012). Approximately 400 plant species from at least 45 plant families have been so far, reported to hyperaccumulate metals. Some of the families are Brassicaceae, Fabaceae, Euphorbiaceae, Asterraceae, Lamiaceae and Scrophulariaceae (Dushekov, 2003). Crops like alpine pennycress (Thlaspi caerulescens), Ipomea alpine, Haumaniastrum robertii, Astragalus racemosus, Sebertia acuminate have very high bioaccumulation potential for $\mathrm{Cd}, \mathrm{Zn}, \mathrm{Cu}, \mathrm{Co}, \mathrm{Se}$ and $\mathrm{Ni}$, respectively. The root of Indian mustard are found to be effective in the removal of $\mathrm{Cd}, \mathrm{Cr}, \mathrm{Cu}, \mathrm{Ni}, \mathrm{Pb}$, and $\mathrm{Zn}$, and sunflower can remove $\mathrm{Pb}, \mathrm{U}, \mathrm{Cs}$ and $\mathrm{Sr}$ from hydroponic solutions (Lone et al., 2008). Rizwan et al. (2016) reported the increase in uptake of copper by Indian mustard and sunflower plant. Nehnevajova et al. (2005) investigated that the highest metal concentration was found in leaves (shoot) of commercial cultivars of sunflower plants grown on metals-contaminated soil. Among the cultivated crops rape and sunflower revealed higher cadmium concentrations in their shoots than in the roots. Nagaraju and Karimulla, (2002) described that some species, including Jatropha curcas (from Euphorbiaceae), Dodonaea viscose (from Sapindaceae) and Cassia auriculata (from Fabaceae), had potential for remediation of soils polluted with different kinds of trace and major elements. Also, high heavy metal accumulating ability has been reported for cereal crops such as maize (Zea mays L.), sorghum (Sorghum bicolor) and alfalfa (Medicago sativa L.) Such plants can be used successfully to clean up heavy metal polluted soils if their biomass and metal content are large enough to complete remediation within a reasonable period (Greenberg et al., 2006).

\subsection{Plant Mechanisms that used for phytoremediation of heavy metal contaminated soil}

Variety of pollutant attenuation mechanisms possessed by plants makes their use in remediating contaminated soil and water more feasible than physical and chemical remediation (Gerhardt et al., 2009). As a result of their sedentary nature, plants have evolved diverse abilities for dealing with toxic compounds in their environment. 
Plants act as solar-driven pumping and filtering systems as they take up contaminants (mainly water soluble) through their roots and transport or translocate them through various plant tissues where they can be metabolized, sequestered, or volatilized (Olguín and Galván, 2012). Plants utilize different types of mechanisms for dealing with environmental pollutants in soil. The mechanisms of phytoremediation include biophysical and biochemical processes like adsorption, transport and translocation, as well as transformation and mineralization by plant enzymes and have been shown to be able to degrade halogenated compounds by oxidative degradation pathways, including plant specific dehalogenases (Meagher, 2000). Plants used different Phytoremediation mechanisms to remove heavy metals from the contaminated soil (Fig 1)

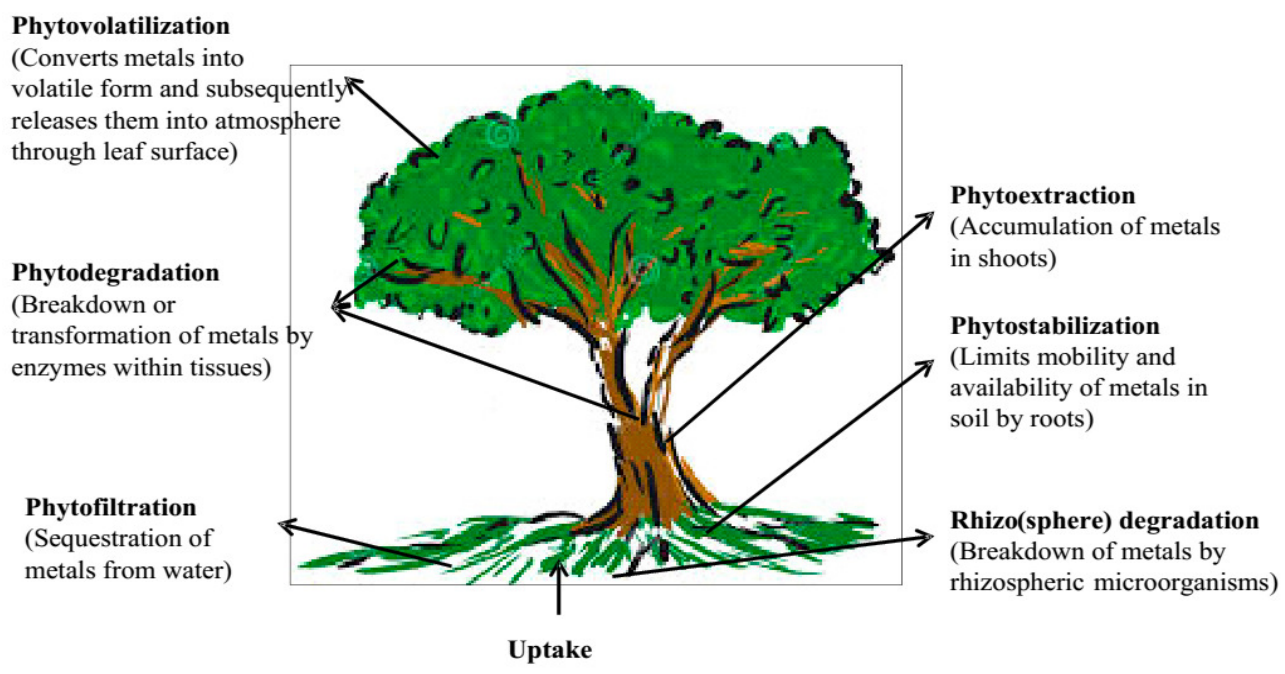

Figure: 1 Mechanisms of phytoremediation, modified from Dixit et al. (2015)

\subsubsection{Phytovolatilization}

Phytovolatilization is the use of green plants to extract volatile contaminants, such as $\mathrm{Hg}$ and Se, from the polluted soils and to ascend them into the air from their foliage (Karami and Shamsuddin, 2010). Once taken up by plants, the contaminants are modified or broken down into volatile forms and thus diffuse from the plants to the atmosphere through open stomata on leaves together with a small amount of redial diffusion through stem tissues and bark (Kamath et al., 2004) In other word, Phytovolatilization involves the use of plants to take up contaminants from the soil, transforming them into volatile forms and transpiring them into the atmosphere (United States Protection Agency, 2000). Banuelos (2000) perceived that some plants were able to transform Se in the form of dimethylselenide and dimethyldiselenide in high-selenium media. Unlike other remediation techniques, once the contaminants have been removed via volatilization, one has no control over their migration to other areas. A similar case of volatilization based soil remediation has also been reported in many recently published reports (Tangahu et al., 2011).

\subsubsection{Phytodegradation}

Phytodegradation is the use of plants and micro-organisms to uptake metabolize and degrade the organic contaminant. In this approach, plant roots are used in association with microorganisms to detoxify soil contaminated with organic compounds (Garbisu and Alkorta, 2001). It is also known as phytotransformation. Some plants are able to decontaminate soil, sludge, sediment, and ground and surface water by producing enzymes. This approach involves organic compounds, including herbicides, insecticides, chlorinated solvents, and inorganic contaminants (Pivetz, 2001). Phytodegradation is the breakdown of organic contaminants within plant tissue. Plants produce enzymes, such as dehalogenase and oxygenase that help catalyze degradation. It appears that both the plants and the associated microbial communities play a significant role in attenuating contaminants. It is referred to the degradation or breakdown of organic contaminants by internal and external metabolic processes driven by the plant (Bhatia and Goyal, 2014).

\subsubsection{Phytoextraction}

Phytoextration is a phytoremediation technique that uses plants to remove heavy metals, such as $\mathrm{Cd}$, from water, soil, and sediments (Van Nevel et al., 2007). It is an ideal method for removing pollutants from soil without adversely affecting the soil's properties. This technology refers that plants absorb metals from soil and translocation them to the harvestable shoots where they accumulate. The roots and shoots are subsequently harvested to remove the contaminants from the soil. Garbisu and Alkorta, (2001) reported that the costs involved in phytoextraction would be more than ten times less per hectare compared to conventional soil remediation techniques. It can be applied in mineral industry to commercially produce metals by cropping. Nascimento and Xing (2006) expressed that phytoextraction may be considered as a commercial technology in the future. Zhang et al. (2009) expressed that as Cd phytoextraction is observed by maize, the percentage of exchangeable form of 
Cd decreased in the planted soil. Similar finding of decrease in Cd level in soil planted with maize have also been reported by Mojiri (2011). It can be applied in mineral industry to commercially produce metals by cropping (Garbisu and Alkorta, 2001). The ability of plants to transport and uptake heavy metals from the soil into their above-ground shoots and the harvestable parts of their underground roots is the key to successful phytoextraction. Moreover, for phytoextraction to be considered successful, the contaminated areas need to be detoxified to a level specified by environmental rules and for a lower cost than conventional techniques (Yanai et al., 2006).

\subsubsection{Phytostabilization}

Phytostabilization is a simple, cost-effective, and less environmental invasive approach to stabilize and reduce the bioavailability of contaminants by using plants. In fact, this approach uses plant roots to restrict the mobility and bioavailability of contaminants in the soil (Bhagure and Mirgane, 2011). Plants can reduce the future adverse effects of pollutants in the environment by keeping them from entering the ground water or spreading in the air. This method is applicable when there is no prompt action to detoxify contaminated areas (Alvarenga et al., 2009). In phytostabilization, plants are responsible for reducing the percolation of water within the soil matrix, which may create a hazardous leachate, inhibiting direct contact with polluted soil by acting as barrier, and interfering with soil erosion, which results in the spread of toxic metals to the other sites. Phytostabilization is a suitable technique to remediate $\mathrm{Cd}, \mathrm{Cu}, \mathrm{As}, \mathrm{Zn}$ and $\mathrm{Cr}$. These reagents immobilized and decreased the mobile fraction of $\mathrm{Cu}, \mathrm{Pb}$ and $\mathrm{Zn}$. It was inferred that ryegrass had the potential to be used in phytostabilization for mine-polluted soil and municipal solid waste compost, and to a lesser extent, sewage sludge, used and that it is efficient in the in situ immobilization of metals, developing the chemical properties of the soil, and greatly enhancing the plant biomass. Some of the advantages associated with this technology are that the disposal of hazardous material/biomass is not required. It is very effective when rapid immobilization is needed to preserve ground and surface waters (Jidah and Chhotu, 2009).

\subsubsection{Rhizoremediation}

The rhizosphere is the zone around plant roots. It is mainly influenced by root secretion and by the root-associated soil microorganisms. The term rhizoremediation refers to the combined use of plants and rhizosphere microorganisms to improve the bioremediation capacity of plants (Gerhardt et al., 2009). As a combination of two methodologies (bioremediation and phytoremediation), rhizoremediation is called as in situ plant-assisted bioremediation or generalized phytoremediation (Olguín and Sánchez, 2012). Plant roots perform a vital role in this process. Roots favor microbial growth by providing habitats, oxygen, nutrients and enzymes. Plant roots provide a large surface area for microbes to colonize and allow them to move to deeper soil layers (Jadia and Chhotu, 2009). Roots also help with oxygen availability either by transporting oxygen or by creating void spaces in the subsurface that allows for greater oxygen diffusion from the atmosphere and accelerating the bioremediation process.

\section{Conclusion}

The increase global population, industrialization and urbanization are the some major reasons to contaminate the environment. The release of heavy metals from industries causing environmental pollution and serious health problem to human and other animals and also pollutes the soil due to their persistence and bio-accumulative nature. In this regards, phytoremediation process provides and effective innovative measures for treatment of a wide variety of heavy metal contaminants. Phytoremediation the use of plants to remove or degrade contamination from soils and surface has been proposed as a cheap, sustainable, effective, and environmentally friendly approach alternative to conventional remediation technologies. Plants use solar energy (through photosynthesis) to extract chemicals from the soil and to deposit them in the above-ground part of their bodies, or to convert them to a less toxic form. Phytoremediation does not require expensive equipment or highly-specialized personnel, thus, it is relatively easy to implement. It is capable of permanently treating a wide range of contaminants in a wide range of environments.

\section{Reference}

Olguín, E.J. and Sánchez-Galván, G., 2012. Heavy metal removal in phytofiltration and phycoremediation: the need to differentiate between bioadsorption and bioaccumulation. New biotechnology, 30(1), pp.3-8.

Aelion, C.M., Davis, H.T., McDermott, S. and Lawson, A.B., 2008. Metal concentrations in rural topsoil in South Carolina: potential for human health impact. Science of the Total Environment, 402(2-3), pp.149-156.

Ali, H., Khan, E. and Sajad, M.A., 2013. Phytoremediation of heavy metals-concepts and applications. Chemosphere, 91(7), pp.869-881.

Alvarenga, P., Gonçalves, A.P., Fernandes, R.M., De Varennes, A., Vallini, G., Duarte, E. and Cunha-Queda, A.C., 2009. Organic residues as immobilizing agents in aided phytostabilization:(I) Effects on soil chemical characteristics. Chemosphere, 74(10), pp.1292-1300.

Bañuelos, G.S., Zambrzuski, S. and Mackey, B., 2000. Phytoextraction of selenium from soils irrigated with selenium-laden effluent. Plant and Soil, 224(2), pp.251-258. 
Bhatia, M. and Goyal, D., 2014. Analyzing remediation potential of wastewater through wetland plants: a review. Environmental Progress \& Sustainable Energy, 33(1), pp.9-27.

Bong, C.W., Malfatti, F., Azam, F., Obayashi, Y. and Suzuki, S., 2010. The effect of zinc exposure on the bacteria abundance and proteolytic activity in seawater. Interdisciplinary studies on environmental chemistrybiological responses to contaminants. Terrapub, Tokyo, pp.57-63.

Bruins, M.R., Kapil, S. and Oehme, F.W., 2000. Microbial resistance to metals in the environment. Ecotoxicology and environmental safety, 45(3), pp.198-207.

Chabukdhara, M., Munjal, A., Nema, A.K., Gupta, S.K. and Kaushal, R.K., 2016. Heavy metal contamination in vegetables grown around peri-urban and urban-industrial clusters in Ghaziabad, India. Human and Ecological Risk Assessment: An International Journal, 22(3), pp.736-752.

Chibuike, G.U. and Obiora, S.C., 2014. Heavy metal polluted soils: effect on plants and bioremediation methods. Applied and Environmental Soil Science, 2014.

Cooper, J., Sanderson, R., Cakmak, I., Ozturk, L., Shotton, P., Carmichael, A., Haghighi, R.S., Tetard-Jones, C., Volakakis, N., Eyre, M. and Leifert, C., 2011. Effect of organic and conventional crop rotation, fertilization, and crop protection practices on metal contents in wheat (Triticum aestivum). Journal of agricultural and food chemistry, 59(9), pp.4715-4724.

Dixit R, Wasiulah, MalaviyaD, PandiyanK, SinghU B, SahuA, ShuklaR, SinghB P, RaiJ P, SharmaP K,LadeH and PaulD 2015Bioremediation of heavy metals from soil and aquatic environment: An overview of principles and criteria of fundamental processes Sustainability72189-212

Dushenkov, S., 2003. Trends in phytoremediation of radionuclides. Plant and soil, 249(1), pp.167-175.

Garbisu, C. and Alkorta, I., 2001. Phytoextraction: a cost-effective plant-based technology for the removal of metals from the environment. Bioresource technology, 77(3), pp.229-236.

Greenberg, B.M., Huang, X.D., Gurska, Y., Gerhardt, K.E., Wang, W., Lampi, M.A., Zhang, C., Khalid, A., Isherwood, D., Chang, P. and Wang, H., 2006. Successful field tests of a multi-process phytoremediation system for decontamination of persistent petroleum and organic contaminants.

Haferburg, G. and Kothe, E., 2007. Microbes and metals: interactions in the environment. Journal of basic microbiology, 47(6), pp.453-467.

Jadia, C.D. and Fulekar, M.H., 2009. Phytoremediation of heavy metals: recent techniques. African journal of biotechnology, 8(6).

Kamath, R., Rentz, J.A., Schnoor, J.L. and Alvarez, P.J.J., 2004. Phytoremediation of hydrocarbon-contaminated soils: principles and applications. In Studies in surface science and catalysis (Vol. 151, pp. 447-478). Elsevier.

Karami, A. and Shamsuddin, Z.H., 2010. Phytoremediation of heavy metals with several efficiency enhancer methods. African Journal of Biotechnology, 9(25), pp.3689-3698.

Liu, S.H., Zeng, G.M., Niu, Q.Y., Liu, Y., Zhou, L., Jiang, L.H., Tan, X.F., Xu, P., Zhang, C. and Cheng, M., 2017. Bioremediation mechanisms of combined pollution of PAHs and heavy metals by bacteria and fungi: A mini review. Bioresource technology, 224, pp.25-33.

Lone, M.I., He, Z.L., Stoffella, P.J. and Yang, X.E., 2008. Phytoremediation of heavy metal polluted soils and water: progresses and perspectives. Journal of Zhejiang University Science B, 9(3), pp.210-220.

Meagher, R.B., 2000. Engineered phytoremediation of mercury pollution in soil and water using bacterial genes. Phytoremediaiton of contaminated soil and water, pp.202-233.

Mireles, F., Davila, J.I., Pinedo, J.L., Reyes, E., Speakman, R.J. and Glascock, M.D., 2012. Assessing urban soil pollution in the cities of Zacatecas and Guadalupe, Mexico by instrumental neutron activation analysis. Microchemical Journal, 103, pp.158-164.

Nagajyoti, P.C., Lee, K.D. and Sreekanth, T.V.M., 2010. Heavy metals, occurrence and toxicity for plants: a review. Environmental chemistry letters, 8(3), pp.199-216.

Nagaraju, A. and Karimulla, S., 2002. Accumulation of elements in plants and soils in and around Nellore Mica Belt, Andhra Pradesh, India-a biogeochemical study. Environmental Geology, 41(7), pp.852-860.

Nehnevajova, E., Herzig, R., Federer, G., Erismann, K.H. and Schwitzguébel, J.P., 2005. Screening of sunflower cultivars for metal phytoextraction in a contaminated field prior to mutagenesis. International Journal of Phytoremediation, 7(4), pp.337-349.

Nicholson, F.A., Smith, S.R., Alloway, B.J., Carlton-Smith, C. and Chambers, B.J., 2003. An inventory of heavy metals inputs to agricultural soils in England and Wales. Science of the total environment, 311(1-3), pp.205219.

Pivetz, B.E., 2001. Ground water issue: phytoremediation of contaminated soil and ground water at hazardous waste sites. NATIONAL RISK MANAGEMENT RESEARCH LAB ADA OK.

Rizwan, M., Ali, S., Rizvi, H., Rinklebe, J., Tsang, D.C., Meers, E., Ok, Y.S. and Ishaque, W., 2016. Phytomanagement of heavy metals in contaminated soils using sunflower: a review. Critical reviews in environmental science and technology, 46(18), pp.1498-1528.

Singh, S. and Aggarwal, P.K., 2006. Effect of heavy metals on biomass and yield of different crop species. Indian 
journal of agricultural science, 76(11), pp.688-691.

Sobolev, S.L., 2008. Some applications of functional analysis in mathematical physics (Vol. 90). American Mathematical Soc..

Tangahu, B.V., Abdullah, S., Rozaimah, S., Basri, H., Idris, M., Anuar, N. and Mukhlisin, M., 2011. A review on heavy metals ( $\mathrm{As}, \mathrm{Pb}$, and $\mathrm{Hg}$ ) uptake by plants through phytoremediation. International Journal of Chemical Engineering, 2011.

Van Aken, B., 2009. Transgenic plants for enhanced phytoremediation of toxic explosives. Current Opinion in Biotechnology, 20(2), pp.231-236.

Van Nevel, L., Mertens, J., Oorts, K. and Verheyen, K., 2007. Phytoextraction of metals from soils: how far from practice?. Environmental Pollution, 150(1), pp.34-40.

Yanai, J., Zhao, F.J., McGrath, S.P. and Kosaki, T., 2006. Effect of soil characteristics on Cd uptake by the hyperaccumulator Thlaspi caerulescens. Environmental Pollution, 139(1), pp.167-175. 